\title{
Impact of small variations in temperature and humidity on the reproductive activity and survival of Aedes aegypti (Diptera, Culicidae)
}

\author{
Ethiene Arruda Pedrosa de Almeida Costa ${ }^{1}$, Eloína Maria de Mendonça Santos ${ }^{1}$, Juliana Cavalcanti Correia ${ }^{1}$ \\ $\&$ Cleide Maria Ribeiro de Albuquerque ${ }^{1}$
}

${ }^{1}$ Departamento de Zoologia - Centro de Ciências Biológicas, Universidade Federal de Pernambuco. Avenida Moraes Rego, 1235, Cidade Universitária 50670-420 Recife-PE, Brasil. ethiene@gmail.com; eloina.santos@gmail.com; juliana.c.correia@gmail.com; cleide.ufpe@gmail.com

\begin{abstract}
Impact of small variations in temperature and humidity on the reproductive activity and survival of Aedes aegypti (Diptera, Culicidae). In short space of time increase in temperature and rainfall can affect vector populations and, consequently, the diseases for them transmitted. The present study analyzed the effect of small temperature and humidity variations on the fecundity, fertility and survival of Aedes aegypti. These parameters were analyzed using individual females at temperatures ranging from 23 to $27^{\circ} \mathrm{C}$ (mean $25^{\circ} \mathrm{C}$ ); 28 to $32^{\circ} \mathrm{C}$ (mean $30^{\circ} \mathrm{C}$ ) and 33 to $37^{\circ} \mathrm{C}$ (mean $35^{\circ} \mathrm{C}$ ) associated to $60 \pm 8 \%$ and $80 \pm 6 \%$ relative humidity. Females responded to an increase in temperature by reducing egg production, oviposition time and changing oviposition patterns. At $25{ }^{\circ} \mathrm{C}$ and $80 \%$ relative humidity, females survived two-fold more and produced $40 \%$ more eggs when compared to those kept at $35^{\circ} \mathrm{C}$ and $80 \%$ relative humidity. However, in $45 \%$ of females kept at $35^{\circ} \mathrm{C}$ and $60 \%$ relative humidity oviposition was inhibited and only $15 \%$ females laid more than 100 eggs, suggesting that the intensity of the temperature effect was influenced by humidity. Gradual reductions in egg fertility at $60 \%$ relative humidity were observed with the increase in temperature, although such effect was not found in the $80 \%$ relative humidity at $25^{\circ} \mathrm{C}$ and $30^{\circ} \mathrm{C}$. These results suggest that the reduction in population densities recorded in tropical areas during seasons when temperatures reach over $35^{\circ} \mathrm{C}$ is likely to be strongly influenced by temperature and humidity, with a negative effect on several aspects of mosquito biology.
\end{abstract}

KEYWORDS. Climate changes; dengue; fecundity; fertility; mosquito.

RESUMO. Impacto de pequenas variações de temperatura e umidade na atividade reprodutiva e sobrevivência de Aedes aegypti (Diptera, Culicidae). Em curto espaço de tempo, um aumento na temperatura e precipitação pode afetar a população de vetores e conseqüentemente, as doenças por eles transmitidas. Nesse estudo, analisou-se o efeito de pequenas variações na temperatura e umidade, sobre fecundidade, fertilidade e sobrevivência de Aedes aegypti. Esses parâmetros foram investigados usando-se fêmeas individuais nas temperaturas: $23-27^{\circ} \mathrm{C}$ (média $25^{\circ} \mathrm{C}$ ), 28-32 ${ }^{\circ} \mathrm{C}$ (média $30^{\circ} \mathrm{C}$ ) e $33-37^{\circ} \mathrm{C}$ (média $35^{\circ} \mathrm{C}$ ) associada à umidade relativa: $60 \pm 8 \%$ e $80 \pm 6 \%$. As fêmeas responderam ao aumento da temperatura com redução na produção de ovos, tempo de oviposição e mudança nos padrões de postura. A $25^{\circ} \mathrm{C}$ e $80 \%$, fêmeas sobreviveram duas vezes mais e produziram $40 \%$ mais ovos, que aquelas mantidas a $35^{\circ} \mathrm{C}$ e $80 \%$. No entanto, nos grupos a $35^{\circ} \mathrm{C}$ e $60 \%$ a postura foi inibida em $45 \%$ das fêmeas e apenas $15 \%$ puseram mais de 100 ovos, sugerindo que a intensidade do efeito da temperatura seja influenciado pela umidade. Reduções graduais na fertilidade a $60 \%$ de umidade relativa foram observadas com o aumento da temperatura, embora esse efeito não tenha sido registrado na umidade de $80 \%$, nas temperaturas de $25^{\circ} \mathrm{C}$ e $30^{\circ} \mathrm{C}$. Esses resultados sugerem que a redução na densidade populacional nas zonas tropicais durante estações, em que a temperatura se eleva acima de $35^{\circ} \mathrm{C}$ pode ser fortemente influenciada pela interação temperatura e umidade, afetando negativamente diversos aspectos da biologia do mosquito.

PALAVRAS-CHAVE. Mudanças climáticas; dengue; fecundidade; fertilidade; mosquito.

One of the most important mosquito-borne diseases affected by climate changes is dengue fever (DF), which continues to spread throughout tropical and subtropical regions worldwide, affecting an estimated 50-100 million people each year, except Europe (WHO 1997).

The greatest effect of climate change, which is expected to raise temperatures an average of 1.0 to $3.5^{\circ} \mathrm{C}$ by the year 2100 (Houghton et al. 1996), is likely to be observed in transmission areas with an extreme temperature range (Githeko et al. 2000). The variability in temperature, precipitation and humidity expected to take place under different climate changes will affect the biology (Chadee 1992; Kalra et al. 1997; Teng \& Apperson 2000) and ecology (Alto \& Juliano 2001; Miciele \& Campos 2003; Vezzani et al. 2004) of mosquito vectors and intermediate hosts as well as the risk of disease transmission (Moore et al. 1978).

The main vector of dengue fever is the mosquito Aedes aegypti (Linnaeus, 1762) originally from northeastern Africa and having spread to other parts of the world, especially tropical and subtropical regions (Gubler 2002). The wide geographic distribution of $A$. aegypti is likely to be associated with variations in its biology (Glasser \& Gomes 2002; Beserra et al. 2006), enabling it to survive in a variety of different environmental conditions. This mosquito species show breeding preferences for domestic water containers having its proliferation influenced by human population growth, general travel, lack of political will, limited financial and human resources to implement effective control measures (WHO 2002).

Studies aiming to understand the effect of temperature on mosquito population dynamics generally investigate variations between 20 and $30{ }^{\circ} \mathrm{C}$ (Joshi 1996; LöwenbergNeto \& Navarro-Silva 2004). However, in tropical areas in which $A$. aegypti is a vector of etiological agents causing 
dengue and yellow fever, mean temperatures are generally high and can rise above $35^{\circ} \mathrm{C}$. Therefore, detailed studies on the effect of abiotic factors on mosquito reproduction under controlled laboratory conditions can contribute to a more precise field data interpretation. A large genetic variation is observed in A. aegypti result in different physiological, bionomic and behavioural aspects amongst close related mosquito population (Ayres et al. 2004). For instance, changes in the duration of the A. aegypti lifecycle that have been described between populations in nearby cities as a result of temperature variations are likely to be associated to mosquito adaptation to local climatic changes (Beserra et al. 2006). Therefore, control strategies depend upon an understanding of local mosquito populacion dinamic would result in practical regional strategies, especially regarding the improvement of vector control programs, such as to indicate the best moment for measure control.

Recife is a coastal city in northeastern Brazil, with temperatures ranging from $22^{\circ} \mathrm{C}$ to $32^{\circ} \mathrm{C}$ and relative air humidity between $70 \%$ and $90 \%$ throughout the year, being a factor that favour mosquito breeding all year round (Regis et al. 2008). Taking into account the predicted temperature increase due to global warming, the aim of the present study was to assess the impact of a small rise in temperature on the reproductive fitness and survival of $A$. aegypti females, originally from the Recife mosquito population. The results broaden knowledge on the biology of this vector, thereby offering support for the improvement of control measures regarding this mosquito species in the area.

\section{MATERIAL AND METHODS}

Mosquitoes. Aedes aegypti females from a laboratory colony, originally formed from eggs collected in ovitraps placed in an urban area of Recife (Lat $08^{\circ} 04^{\prime} \mathrm{S}$ Long $34^{\circ} 52^{\prime} \mathrm{W}$ ), Brazil, were used as biological material in this study. The city of Recife has two seasons (rainy and dry), with maximal temperatures reaching over $35^{\circ} \mathrm{C}$ in the dry season. For colony maintenance, larvae were routinely reared in plastic containers $(40 \times 27 \times 7,5 \mathrm{~cm})$ with tap water and fed with commercial cat food $(0.04 \mathrm{mg} / \mathrm{larva})$ under laboratory conditions $\left(27 \pm 2{ }^{\circ} \mathrm{C} ; 70 \pm 5 \%\right.$ relative humidity and a photoperiod of 12:12 L:D) stimated using a using a thermo-hygrometer (INCOTERM). Adults were maintained with a $10 \%$ sucrose solution and females were fed on mice in order to stimulate egg production.

Effect of the temperature and humidity on fecundity and survival. Fecundity was estimated based on the number of eggs laid by females in the first gonotrophic cycle, which, according to Suleman (1990), is a prognosis of total fecundity.

Six experimental groups were performed, using females randomly and individually separated into plastic containers $(300 \mathrm{ml})$ immediately following the blood meal. Four consecutive experiments were carried out, using 20 to 37 female/trial, each female being considered a replicate, in the following conditions: females maintained at temperatures ranging from 23 to $27^{\circ} \mathrm{C}$ (mean: $25^{\circ} \mathrm{C}$ ) and relative humidity of $60 \pm 8 \%(n=113)$ or $80 \pm 6 \%(n=105)$; from 28 to $32{ }^{\circ} \mathrm{C}$ (mean: $30{ }^{\circ} \mathrm{C}$ ) combined with relative humidity of $60 \pm 8 \%$ $(n=149)$ or $80 \pm 6 \%(n=100)$; from 33 to $37^{\circ} \mathrm{C}$ (mean: 35 $\left.{ }^{\circ} \mathrm{C}\right)$ and relative humidity of $60 \pm 8 \%(\mathrm{n}=100)$ or $80 \pm 6 \%(\mathrm{n}=$ 110).

Throughout this paper, mean values are used to refer each experimental setting. Temperature and humidity readings were taken twice daily. Daily oviposition was observed on water-soaked filter paper (9 $\mathrm{cm}$ in diameter) inserted in the container as an oviposition substrate. The substrates were left to dry for seven days under the same experimental conditions of their respective groups and were then analyzed under an optical microscope (x10) for the determination of the number of eggs laid. Survival rate was estimated from the number of living individuals in each group during daily observations in females deprived from suggar feeding. Feeding on fructose is relatively rare for wild $A$. aegypti, living in the dwellings of their human hosts and seems do not affect survival and reproductin (Edman et al. 1992; Harrington et al. 2001).

Influence of temperature and humidity variations on hatching rate. From each setting, a group of eggs was randomly selected for the investigation of hatching rate. The eggs were placed in plastic trays with tap water (2 liters) for larvae hatching. Larvae were counted and fed on cat food $(0.04 \mathrm{mg} / \mathrm{larva})$. After pupation, the individuals were collected, placed in plastic containers and placed into cages for adult emergence. Afterwards, the adults were analyzed to determine sexual proportion.

Statistical analysis. Statistical analysis were performed using the BioEstat ${ }^{\circledR} 5.0$ for Windows. The effects of temperature and humidity on oviposition rate, egg hatching and survival were analyzed with two-way analysis of variance (ANOVA, Tukey a posteriori test). Data were previously tested for normality using the Kolmogorov-Smirnov test and when represented by percentages, the data were transformed by the square root of the percentile divided by 100 . The influence of abiotic factors on the mean number of eggs laid and survival rate of $A$. aegypti females was estimated using the Student's $t$-test and simple linear regression, respectively.

\section{RESULTS}

Fecundity and Survival. The effect of temperature and humidity on fecundity in the first gonotrophic cycle of $A$. aegypti females was investigated in 678 individuals. Both temperature and humidity influenced the number of eggs laid as well as the number of females that laid eggs (Table I). A reduction in oviposition rate was observed with the increase in temperature, whereas the intensity of the reduction was influenced by humidity. The lowest oviposition rate (mean = $54.53 \pm 4.81$ eggs) was recorded in the group of females kept at the highest temperature and lower humidity $\left(35^{\circ} \mathrm{C}\right.$ and $60 \%$ relative humidity). Contrarily, the highest rate (mean $=$ $99.08 \pm 3.56$ eggs) was obtained at the lowest temperature $(25$ ${ }^{\circ} \mathrm{C}$ ) and higher humidity (80\%) (Table I). 

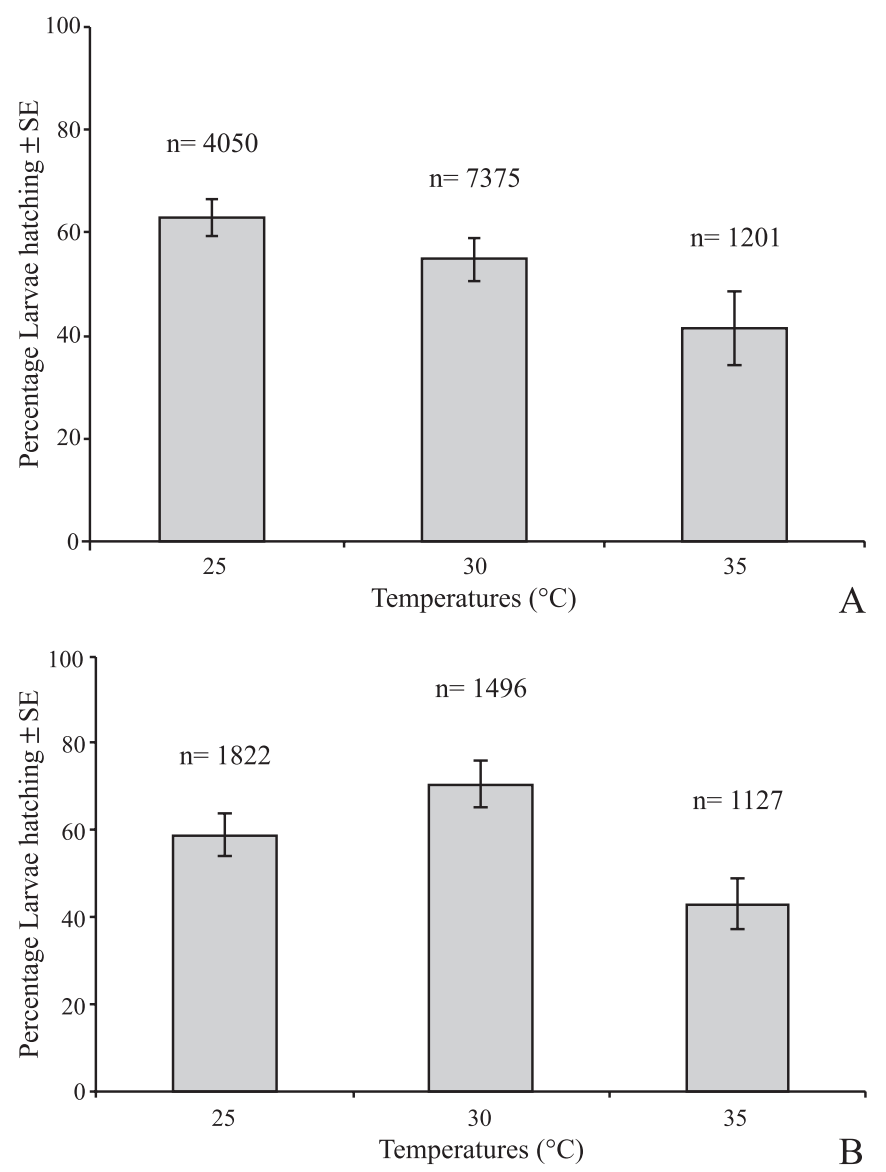

Fig. 1. Fertility rates of eggs maintained under different temperature and humidity. A - 60\% rh; B- $80 \%$ rh. $\mathrm{n}=$ number of eggs analysed.

A significant reduction in number of eggs laid occurred as the temperature increased $(\mathrm{F}=25.8198, \mathrm{df}=243, \mathrm{p}<0.01)$ and the humidity was kept at $80 \%$. Under this condition, a reduction of $23.5 \%$ in the mean number of eggs laid by females submitted to $35{ }^{\circ} \mathrm{C}$ (mean $=75.75 \pm 5.03$ ) was observed in comparison to those maintained at $25{ }^{\circ} \mathrm{C}$. This decrease was more evident (approximately $40 \%$ ) when the base temperature $\left(25^{\circ} \mathrm{C}\right)$ was increased by $10^{\circ} \mathrm{C}$ (Table 1$)$. The effect of temperature on egg production was less evident in females maintained at the lower humidity $(60 \%)$. At this humidity setting, a significant reduction was only recorded in the group kept at $35^{\circ} \mathrm{C}$ in comparison to the other temperatures tested $(\mathrm{F}=170.418$, df $=265, \mathrm{p}<0.01)$. Although females kept at $30^{\circ} \mathrm{C}$ laid fewer eggs on average than at $25^{\circ} \mathrm{C}$ (Table $1)$, the differences between groups did not achieve statistical significance.

Variations in temperature and humidity also affected the number of females laying eggs, particularly at higher temperatures and lower humidity. On average, only $11 \%$ $(113 / 102)$ of the females had their oviposition inhibited when kept at $25{ }^{\circ} \mathrm{C}$. This number doubled at $30^{\circ} \mathrm{C}$ at both humidity settings $(60 \%=149 / 111 ; 80 \%=100 / 75)$. At 35 ${ }^{\circ} \mathrm{C}$, 1.6-fold more females had their oviposition inhibited at $60 \%$ humidity $(100 / 55)$ in comparison to $80 \%(110 / 79)$. At temperatures of 25 and $30{ }^{\circ} \mathrm{C}$, approximately $44 \%$ of the females laid over 100 eggs. At the highest temperature (35
${ }^{\circ} \mathrm{C}$ ), this number was reduced to $14.5 \%$ and $7.6 \%$ at $60 \%$ and $80 \%$ relative humidity, respectively (Table I). Despite being negatively affected by temperature, no significant effect from humidity was recorded for the daily oviposition pattern $(60 \%$ relative humidity, $\mathrm{F}=785.93, \mathrm{df}=333, \mathrm{p}<0.01 ; 80 \%$ relative humidity, $\mathrm{F}=777.89$, $\mathrm{df}=273, \mathrm{p}<0.01$ ).

The lifespan and number of surviving females varied under the different experimental conditions. The maximal survival period for females kept at $35{ }^{\circ} \mathrm{C}$ after feeding was 5 days. This period was two days longer in the group kept at $30{ }^{\circ} \mathrm{C}$. At the mildest temperature $\left(25^{\circ} \mathrm{C}\right)$, lifespan was prolonged for up to 11 days and was strongly dependent on humidity (Table II).

Regression analysis revealed that survival is significantly reduced with largely the increase in temperature $\left(\mathrm{R}^{2}=18.60 \%\right.$, $\mathrm{b}=-0.0649, \mathrm{df}=87, \mathrm{p}<0.01)$. The effect of the relative humidity on the lifespan was less evident $(\mathrm{F}=0.1515$, $\mathrm{df}=$ $110, p=0.7000$ ), althgout a pattern favoring survival at 25 and $35^{\circ} \mathrm{C}$ was observed when females were submitted to the higher humidity, whereas the opposite was found in groups kept at $30^{\circ} \mathrm{C}$ (Table II).

Oviposition time exhibited three distinct temporal patterns: the longest oviposition period occurred in females kept at $25{ }^{\circ} \mathrm{C}$, regardless of humidity. At this temperature, oviposition was prolonged for up to 5 days, with an average of $52.9 \pm 6.19$ and $75.01 \pm 8.12 \mathrm{eggs} /$ female/day at $60 \%$ and $80 \%$ relative humidity, respectively. Females kept at $30{ }^{\circ} \mathrm{C}$ and $60 \%$ humidity laid eggs up to three days, with a concentration of oviposition on the first day; only two females laid eggs on the third day. During the first two days, females maintained at $30^{\circ} \mathrm{C}$ laid a similar number of eggs under both humidity settings. However, on the third day, 2.3-fold more eggs were laid at $80 \%$ humidity $(117.67 \pm 10.04)$ in comparison to the lower humidity. The shortest oviposition period (2 days) was recorded at $35{ }^{\circ} \mathrm{C}$, in which $99 \%$ of the females laid their eggs three days after the blood meal. At this temperature,

Table I. Mean number of eggs laid by Aedes aegypti females under different temperature and humidity.

\begin{tabular}{|c|c|c|c|c|}
\hline \multirow[b]{2}{*}{$\begin{array}{l}\text { Tempe- } \\
\text { ratures }\end{array}$} & \multicolumn{2}{|c|}{$60 \%$ rh } & \multicolumn{2}{|c|}{$80 \%$ rh } \\
\hline & $\begin{array}{c}\text { Eggs } \\
\text { mean } \pm \text { SE } \\
(n)\end{array}$ & $\begin{array}{c}\text { Oviposition } \\
\text { variation } \\
\text { (y) }\end{array}$ & $\begin{array}{c}\text { Eggs } \\
\text { mean } \pm \text { SE } \\
(n)\end{array}$ & $\begin{array}{l}\text { Oviposition } \\
\text { variation } \\
\text { (y) }\end{array}$ \\
\hline $25^{\circ} \mathrm{C}$ & $\begin{array}{c}85.99 \pm 3.16^{\text {a, B }} \\
(102)\end{array}$ & $\begin{array}{c}4-160 \\
(37.25 \%)\end{array}$ & $\begin{array}{c}99.08 \pm 3.56^{\mathrm{a}} \\
(92)\end{array}$ & $\begin{array}{c}4-155 \\
(55.43 \%)\end{array}$ \\
\hline $30^{\circ} \mathrm{C}$ & $\begin{array}{c}82.89 \pm 3.33^{\mathrm{b}, \mathrm{B}} \\
\text { (111) }\end{array}$ & $\begin{array}{c}2-143 \\
(37.84 \%)\end{array}$ & $\begin{array}{c}75.75 \pm 5.03^{b} \\
(75)\end{array}$ & $\begin{array}{c}1-144 \\
(45.33 \%)\end{array}$ \\
\hline $35^{\circ} \mathrm{C}$ & $\begin{array}{c}54.53 \pm 4.81^{\mathrm{c}} \\
(55)\end{array}$ & $\begin{array}{c}1-126 \\
(14.55 \%)\end{array}$ & $\begin{array}{c}59.62 \pm 3.41^{\mathrm{c}} \\
\text { (79) }\end{array}$ & $\begin{array}{l}2-132 \\
(7.59 \%)\end{array}$ \\
\hline TOTAL & $\begin{array}{c}78.25 \pm 2.2 \\
(268)\end{array}$ & & $\begin{array}{c}79.29 \pm 2.53 \\
(246)\end{array}$ & \\
\hline
\end{tabular}

$\mathrm{n}=$ number of females laid eggs. $\mathrm{y}=$ percentage of females with total ovipositions $\geq 100$ eggs.

Capital letters indicate comparison of values in the same column and small letters show comparison among values in the same line. Regardless of the size same letters represent values without significant differences. Different letters means numbers statistic different $(\mathrm{p}<0,05)$. 


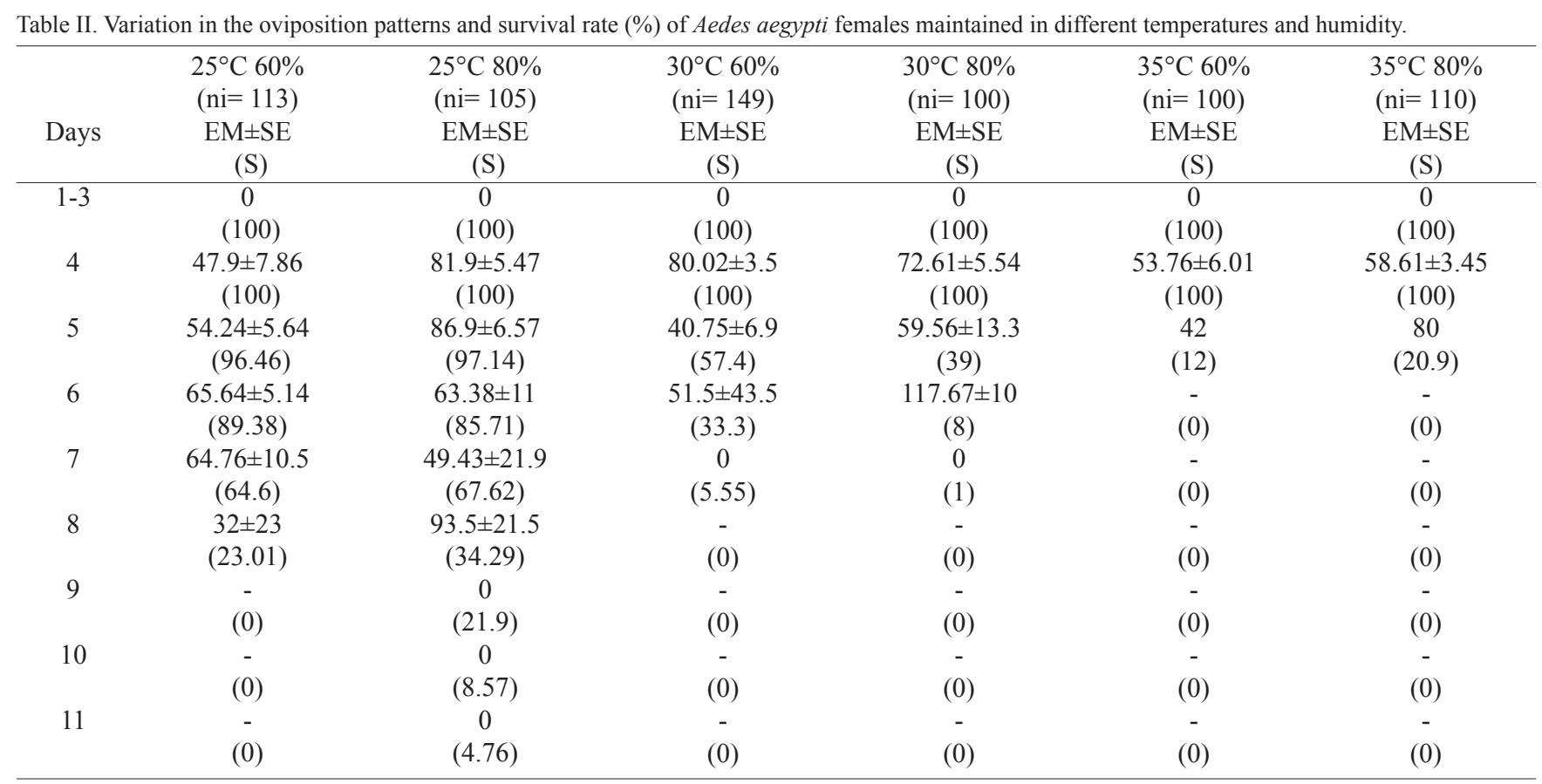

ni= initial number of females. $\mathrm{EM}=$ egg mean. $\mathrm{S}=$ survival rate $(\%)$.

only one female in each setting laid eggs for two consecutive days, although about $21 \%$ and $12 \%$ of females kept at $80 \%$ and $60 \%$ humidity, respectively, were still alive in this period (Table II).

Fertility. The daily hatching rate under different temperature and humidity conditions is illustrated in Figure 1. The percentage of larvae obtained from eggs kept at $60 \%$ humidity reduced gradually with the increase in temperature (Figure 1A). At this humidity, eggs laid at $25{ }^{\circ} \mathrm{C}(2542$ larvae/4050 eggs) led to about $10 \%$ and $20 \%$ more larvae than eggs laid at $30{ }^{\circ} \mathrm{C}$ (4324 larvae/7375 eggs) and $35^{\circ} \mathrm{C}(513$ larvae/1201 eggs), respectively $(\mathrm{F}=3.2925, \mathrm{df}=2, \mathrm{p}<0.05)$.

At the higher humidity $(80 \%)$, egg viability remained similar at 25 and $30{ }^{\circ} \mathrm{C}$, with mean value of $58.88 \pm 4.87 \%$ and $70.67 \pm 5.56 \%$ (Figure $1 \mathrm{~B}$ ); there was a significant reduction at $35{ }^{\circ} \mathrm{C}(43.08 \pm 5.89)(\mathrm{F}=51.002, \mathrm{df}=2, \mathrm{p}<0.05)$. At both humidity settings, eggs kept at $25{ }^{\circ} \mathrm{C}$ for one week produced approximately twice as many males than females (60\%: 1079/599; 80\%: 453/257). The effects of temperature and humidity on other groups were less conclusive. At $60 \%$ relative humidity, eggs kept at 30 and $35^{\circ} \mathrm{C}$ led to a female to male ratio of $1: 1.7$ and $1: 1.1$, respectively. Inverse proportions were recorded for eggs kept at $80 \%$ humidity at these temperatures (female to male ratio at $30{ }^{\circ} \mathrm{C}-1: 1.1$; at $\left.35^{\circ} \mathrm{C}-1: 2\right)$.

\section{DISCUSSION}

In the present study, the local $A$. aegypti strain proved sensitive to a low range of warmth (average $3{ }^{\circ} \mathrm{C}$ ), reducing egg production and survival as well as changing daily oviposition patterns with an increase in temperature. However, the intensity of the temperature effect was strongly associated to humidity. These results and the data in the literature demonstrate the role of temperature and humidity on mosquito population dynamics (Glasser \& Gomes 2002; Miciele \& Campos 2003; Beserra et al. 2006). High rates of adult mortality and decreased oviposition causing severe reductions mosquito densities have frequently been associated to a rise in temperature (Reeves et al. 1994; Oda et al. 1999; Alto \& Juliano 2001; Afrane et al. 2006) and humidity (Canyon et al. 1999). In Anopheles krombeini (Huang, 1975), the fecundity and longevity of females were drastically reduced between 30 and $33.5^{\circ} \mathrm{C}$ when compared to individuals kept at $26^{\circ} \mathrm{C}$ (Joshi 1996).

The results of the present study also corroborate data in the literature indicating that other important mosquito features, such as daily oviposition pattern, hatching rate and sex proportion, are also influenced by these factors. The production of eggs was also dependent on humidity, with higher oviposition rates observed at the lowest temperature $\left(25^{\circ} \mathrm{C}\right)$ and higher humidity $(80 \%)$. The inverse was obtained at $35{ }^{\circ} \mathrm{C}$ and $60 \%$ humidity, in which the number of eggs laid was severely reduced. Adult survival and hatching rate were also affected by the rise in temperature and lower humidity. These results suggest that the reduction in $A$. aegypti population density during hot, dry periods of the year is not only dependent on a reduction in breeding sites, but also is influenced by the effect of high temperature and low humidity on several aspects of mosquito biology. In fieldwork carried out in Recife, Regis et al. (2008) found Aedes spp. oviposition activity the year round, with marked fluctuations in time (means ranging from 100 to 2500 eggs per trap-cycle). However, egg density was generally higher from January to August, a period that includes the rainy season (May to August). 
The higher oviposition rate recorded at the higher humidity agrees with results described by Canyon et al. (1999), who observed significantly higher oviposition rates in A. aegypti females kept at $84 \%$ relative humidity when compared to individuals submitted to lower humidity (34\%). The reproductive cost caused under conditions of environmental stress may be due to the redistribution of nutrients to provide the individuals subsistence that would otherwise be used for egg production (Chadee 1997). This physiological modification can be compared to the gonotrophic dissociation induced by unfavorable environmental conditions (Omer \& Cloudsley-Thompson 1970). Thus, blood normally used for egg production would be used for the survival of the females (Nayar \& Sauerman 1975), thereby reducing fecundity during the unfavorable periods.

At mild temperatures $\left(25^{\circ} \mathrm{C}\right)$, the period of oviposition can be extended for up to 5 days, resulting in an approximately $43 \%$ increase in the number of eggs in the environment when compared to conditions of high temperatures $\left(35^{\circ} \mathrm{C}\right)$. These results suggest that $A$. aegypti populations in hot climates can nearly double in periods with mild temperatures. As this species can distribute the eggs of a same batch among several oviposition substrates (Reiter et al. 1995), it is likely that mild weather conditions would be the most favorable period for the dispersion of the mosquito. Variations in humidity appear not to influence the beginning or duration of the oviposition period, which exhibited a similar pattern in all experiments.

Higher temperatures reduced the survival of the females, although the differences were also dependent on humidity. When kept at $25^{\circ} \mathrm{C}$ and $80 \%$ relative humidity, the lifespan was extended for up to 11 days. This number was reduced by half when submitted to $35^{\circ} \mathrm{C}$, regardless of the relative humidity. Adult dehydration caused by high temperatures and low humidity is likely to be the most important factor affecting survival (Nayar 1972; Reeves et al. 1994; Joshi 1996; Mogi et al. 1996) and could influence the population size of these insects in the environment (Alto \& Juliano 2001). Under similar temperature conditions as those used in the present study $\left(26\right.$ and $30{ }^{\circ} \mathrm{C}$ and $80 \%$ relative humidity), An. krombeini females were found to survive an average of six-fold and four-fold more, respectively, than the A. aegypti females analyzed in the present study. However, at more adverse temperature conditions $\left(35^{\circ} \mathrm{C}\right)$, $A$. aegypti demonstrates greater durability, surviving for five days longer when compared to An. krombeini females (Joshi 1996). Temperature and humidity variations contribute toward the dehydration of individuals, for which resistance to these phenomena is differentiated between species as well as strains of the same species (Mogi et al. 1996). According to Mogi et al. (1996), A. aegypti and Aedes albopictus (Skuse, 1894) in urban areas are more resistant to desiccation than cospecific strains in rural areas, suggesting that this attribute is important to the survival of these mosquitoes in urban areas where there is limited vegetation and low humidity.

Eleven days survival under $25{ }^{\circ} \mathrm{C}$ and $80 \%$ relative humidity observed in our work corroborate data described for A. aegypti reared at $27^{\circ} \mathrm{C} 75 \%$ relative humidity and feeding on rodent blood deprived from suggar feeding (Harrington et al. 2001). Althought, in laboratory studies it is an usual practice to provide sugar to experimental mosquitoes (Gerberg 1970), several works have accumulated evidences that wild females do not need to feed on sugar to survive and reproduce (Edman et al. 1992; Van Handel et al. 1994; Costero et al. 1998). A. aegypti appears to be able to obtain the nutrients necessary for survival and reproduction by feeding frequently on blood (Van Handel et al. 1994; Scott et al. 2000).

High temperatures associated to low humidity also resulted in a decrease in the hatching rate of $A$. aegypti larvae. With the increase in temperature, a gradually smaller number of larvae were produced from eggs kept at $60 \%$ relative humidity. The opposite occurred at $80 \%$ relative humidity, at which there was an increase in hatching rate with the rise in temperature from 25 to $30^{\circ} \mathrm{C}$. An increase in the hatching rate associated to a rise in temperature has been reported in previous studies (Alto \& Juliano 2001). Studying the hatching rate of Anopheles albimanus (Wiedemann, 1820), Ramsey et al. (1988) found that eggs kept at $30^{\circ} \mathrm{C}$ produced a larger amount of larvae than those kept at $25^{\circ} \mathrm{C}$. This species deposits its eggs on the water surface in flooded oviposition sites exposed to intense sunlight. A. aegypti preferentially lays its eggs in the substrate on the border of oviposition sites in shady places. Therefore, A. albimanus eggs are more adapted to temperature variations, whereas $A$. aegypti eggs experience a greater impact from humidity.

In summary, the results regarding the effect of the temperature and humidity on the reproductive aspects of $A$. aegypti contribute toward the understanding of the population dynamics of this mosquito, particularly in hot areas, where the temperature in the summer often rises above $30^{\circ} \mathrm{C}$. The greater concentration of $A$. aegypti in warm, rainy seasons is strongly influenced by the effects of temperature and humidity on several aspects of the mosquito lifecycle. The rise in population density favors the occurrence of epidemics in warm, rainy seasons, decreasing in drier periods, when the number of females in the environment is reduced.

\section{REFERENCES}

Afrane, Y. A.; G. Zhou ; B. W. Lawson ; A. K. Githeko \& G. Yan. 2006. Effects of microclimatic changes caused by deforestation on the survivorship and reproductive fitness of Anopheles gambiae in Western Kenya Highlands. American Journal of Tropical Medicine and Hygiene 74: 772-778.

Alto, B. W. \& S. A. Juliano. 2001. Precipitation and temperature effects on populations of Aedes albopictus (Diptera: Culicidae): implications for range expasion. Journal of Medical Entomology 38: 646-656.

Ayres, C. F. J.; J. R. M. Prota; M. A. V. Melo; L. N. Régis; A.M. Solé-Cava \& A. F. Furtado. 2004. Genetic structure of natural populations of Aedes aegypti at the micro and macro-geographic levels in Brazil. Journal of the American Mosquito Control Association 4: 350-356.

Beserra, E. B.; F. P. Castro Jr.; J.W. Santos; T. S. Santos \& C. R. M. Fernandes. 2006. Biologia e Exigências Térmicas de Aedes aegypti (L.) (Diptera: Culicidae) Provenientes de Quatro Regiões Bioclimáticas da Paraíba. Neotropical Entomology 35: 853-860.

Canyon, D. V.; J. L. K. Hii. \& R. Muller. 1999. Adaptation of Aedes aegypti (Diptera: Culicidae) oviposition behaviour in response to humidity and diet. Journal of Insect Physiology 45: 959-964. 
Chadee, D. D. 1992. Seasonal incidence and horizontal distribution patterns of oviposition by Aedes aegypti in an urban environment in Trinidad, West Indies. Journal of the American Mosquito Control Association 8: $281-284$.

Chadee, D. D. 1997. Effects of forced egg-retention on the oviposition patterns of female Aedes aegypti (Diptera: Culicidae). Bulletin of Entomological Research 87: 649-651.

Costero, A.; G. M. Attardo; T. W. Scott \& J. D. Edman.1998. An experimental study on the detection of fruc-tose in Aedes aegypti. Journal of the American Mosquito Control Association 14: 234-242.

Edman, J. D.; D. Strickman; P. Kittayapong, \& T. W. Scott. 1992. Female Aedes aegypti (Diptera: Culicidae) in Thailand rarely feed on sugar. Journal of Medical Entomology. 29: 1035-1038.

Githeko, A. K.; S. W. Lindsay, U. E. Confalonieri \& J. A. Patz. 2000. Climate change and vector-borne diseases: a regional analysis. Bulletin of the World Health Organization 78: 1136-1147.

Gerberg, E. J. 1970. Manual for mosquito rearing and ex-perimental techniques. American Mosquito Control Association Bulletin 5: 109 p.

Glasser, C. M. \& A. C. Gomes. 2002. Climate and the superimposed distribution of Aedes aegypti and Aedes albopictus on infestation of São Paulo State, Brazil. Revista de Saúde Pública 36:166-172.

Gubler, D. J. 2002. Epidemic dengue/ dengue hemorrhagic fever as a public health, social and economic problem in the 21 st century. Trends of Microbiology 10: 100-103.

Harrington, L. C.; J. D. Edman \& T. W.Scott. 2001. Why do female Aedes aegypti (Diptera: Culicidae) feed preferentially and frequently on human blood? Journal Medical Entomology 38: 411-422.

Houghton, J. T.; L. G. Meira Filho; B. A. Callander; N. Harris; A. Kattenberg \& K. Maskell (eds). 1996. Climate Change 1995: the science of climate change. Cambridge, Cambridge University Press, xii +572 p.

Joshi, D. S. 1996. Effect of fluctuating and constant temperatures on development, adult longevity and fecundity in the mosquito Aedes krombeini. Journal of Thermal Biology 21: 151-154.

Kalra, N. L.; S. M. Kaul \& R. M. Rastogi. 1997. Prevalence of Aedes aegypti and Aedes albopictus - Vectors of Dengue and Dengue haemorrhagic fever in North, North-East and Central India. Dengue Bulletin 21: $84-92$.

Lowënberg Neto, P. \& M. A Navarro-Silva. 2004. Development, longevity, gonotrophic cycle and oviposition of Aedes albopictus Skuse (Diptera: Culicidae) under cyclic temperatures. Neotropical Entomology 33: 29-33.

Micieli, M. V. \& R. E. Campos. 2003. Oviposition activity and seasonal pattern of a populations of Aedes (Stegomyia) aegypti (L.) (Diptera: Culicidae) in Subtropical Argentina. Memórias do Instituto Oswaldo Cruz 98: 659-663.

Mogi, M.; I. Miyagi; K. Abadi \& Syafruddin. 1996. Inter- and intraspecific variation in resistance to desiccation by adult Aedes (Stegomyia) spp. (Díptera: Culicidae) from Indonésia. Journal of Medical Entomology 33: $53-57$.

Moore, C. G.; B. L Cline; E. Ruiz-Tíben; D. Lee, H. Romney-Joseph, \& E. Rivera-Correa. 1978. Aedes aegypti in Puerto Rico: environmental determinants of larval abundance and relation to dengue virus transmission. American Journal of Tropical Medicine and Hygiene 27: $1225-1231$.
Nayar, J. K. 1972. Effects of constant and fluctuating temperatures on life span of Aedes taeniorhynchus adults. Journal of Insect Physiology 18: 1303-1313.

Nayar, J. K. \& D. M. Sauerman. 1975. The effects of nutrition on survival and fecundity in Florida mosquitoes. Part 2. Utilization of blood meal for survival. Journal of Medical Entomology 12: 99-103.

Oda, T.; K. Uchida; A. Mori; M. Mine, Y. Eshita; K. Kurokawa; K. Kato \& H. Tahara.1999. Effects of high temperature on the emergence and survival of adult Culex pipiens molestus and Culex quinquefasciatus in Japan. Journal of the American Mosquito Control Association 15: $153-156$.

Omer, S. M. \& J. L. Cloudsley-Thompson. 1970. Survival of female Anopheles gambiae Giles through a 9-month dry season in Sudan. Bulletin of the World Health Organization 42: 319-330.

Ramsey, J. M.; E. Salinas; J. R. Lopez; G. Del Angel-Cabañas; L. Martinez \& D. N. Bown. 1988. Laboratory oviposition, fecundity and egg hatching ability of colonized Anopheles albimanus from Southwestern Mexico. Journal of the American Mosquito Control Association 4: 509-515.

Reeves, W. C.; J. L. Hardy; W. K. Reisen \& M. M. Milby. 1994. Potential effect of global warming on mosquito-borne arboviruses. Journal of Medical Entomology 31: 323-332.

Regis, L.; A. M. Monteiro; M. A. V. Melo-Santos; J. C. Silveira Jr; A. F. Furtado; R. V. Acioli; G. M. Santos; M. Nakazawa; M. S. Carvalho \& P. J. Ribeiro; \& W. V. Souza. 2008. Developing new approaches for detecting ans preventing Aedes aegypti population outbreaks: bases for surveilance, alert and control system. Memórias do Instituto Oswaldo Cruz 103: 50-59.

Reiter, P.; M. A. Amador; R. A. Anderson \& G. G. Clark. 1995. Short report: Dispersal of Aedes aegypti in an urban area after blood feeding as demonstrated by rubidium-marked eggs. American Journal of Tropical Medicine and Hygiene 52: 177-179.

Scott, T. W.; P. H. Amerasinghe; A. C. Morrison; L. H.Lorenz; G. G. Clark; D. Strickman; P. Kittayapong \& J. D. Edman. 2000. Longitudinal studies of Aedes aegypti (Diptera:Culicidae) in Thailand and Puerto Rico:Blood feeding frequency. Journal of Medical Entomology 37: 89-101.

Suleman, M. 1990. Intraespecific variation in the reproductive capacity of Anopheles stephensi (Diptera: Culicidae). Journal of Medical Entomology 27: 819-828.

Teng, H. J. \& C. S. Apperson. 2000. Development and survival of immature Aedes albopictus and Aedes triseriatus (Diptera: Culicidae) in the laboratory: Effects of density, food, and competition in response to temperature. Journal of Medical Entomology 37: 40-52.

Van Handel, E.; J. D. Edman; J. F. Day; T. W. Scott; G. G. Clark; P. Reiter \& H. C. Lynn. 1994. Plant-sugar, gly-cogen, and lipid assay of Aedes aegypti collected in urban Puerto Rico and rural Florida. Journal of the American Mosquito Control Association 10: 149-153.

Vezzani, D.; S. M. Velásquez \& N. Schweigmann. 2004. Seasonal pattern of abundance of Aedes aegypti (Diptera: Culicidae) in Buenos Aires City, Argentina. Memórias do Instituto Oswaldo Cruz 99: 351-356.

World Health Organization. 1997. Dengue Haemorrhagic Fever. Diagnosis, Treatment, Prevention and Control. Geneva, WHO, vii+84 p.

World Health Organization. 2002. Dengue Fever and Dengue Haemorrhagic Fever Prevention and Control. WHO, Geneva. www. who.int/gb/ebwha/pdf_files/WHA55/ewha5517.pdf [accessed 3 March 2008].

Received 19/05/2009; accepted 15/07/2010

Editor: Mário Antonio Navarro da Silva

Revista Brasileira de Entomologia 54(3): 488-493, setembro 2010 